\title{
Global Warming Effect and Awareness
}

\author{
Hossain $A^{*}$ \\ Wuchang Shipbuilding Industry Co Ltd., China
}

Submission: March 24, 2017; Published: June 19, 2017

*Corresponding author: Hossain A, Chief Naval Architect and Marine Engineer, BN Guided Missile Corvette Project, Wuchang Shipbuilding Industry Co Ltd, Wuhan, China, Tel: 0086-18251320510; Email: akhterengineer@yahoo.com

\begin{abstract}
The biggest cause of global warming is the carbon dioxide released when fossil fuels, mainly oil and coal are burned for energy. Depending on future greenhouse gas emissions, sea levels will raise an average of $16-24$ inch or $40-62 \mathrm{~cm}$ by 2100 . Poor countries are Most Affected by Climate Change and Need the Support of the industrialized countries to Adapt to the Unavoidable Risks. It is unwise to blame the poor countries for this. Climate change is real, it is happening, and it is affecting the poorest, most vulnerable humans most of all. If our species wants to avoid widespread suffering and massive battles over resources due to millions or billions of climate refugees, we're going to have to come together.
\end{abstract}

Keywords: Global warming; Greenhouse gas; Earth's climate; Energy saving

Abbreviations: IPCC: Intergovernmental Panel on Climate Change; $\mathrm{CO}_{2}$ : Carbon Dioxide; WB: World Bank; WHO: World Health Organization; UNFCCC: United Nations Framework Convention on Climate Change

\section{Introduction}

It is interesting to know that a teaspoon of diesel fuel contains as much energy as a human can expend in a day. The transition from diffuse/currently available solar energy to stored/concentrated solar energy transformed every aspect of society, from manufacturing to agriculture; to transportation to life expectancy. Basically, the last 200 years of exponential industrial and population growth have been subsidized by ancient, compacted sunlight. Capitalism started to displace feudalism as the dominant socioeconomic system on the earth just before 500 years ago [1]. There were about half a billion humans wandering around then, and about $80 \%$ of them were living hand-to-mouth existences and relying on subsistence agriculture. It wasn't until the replacement of animate energy or biomass with inanimate energy or fossil fuels in the West during the 19th century and that lead to global population started to grow exponentially [2]. Now the population on earth is around 8 billion. More interesting is that, it took about 200,000 years for the human population to reach 1 billion ( 1800 CE), 130 years to reach 2 billion, 30 years for 3 billion, 15 years for 4 billion, and around 13 years each for $5,6,7$, and 8 billion. The UN is predicting that reaching 9 billion will take around 18 years. It's probably not a coincidence that this growth corresponds pretty closely with the easy availability of ancient stores of fossilized energy [3]. It is really surprising that without fossil fuels, the carrying capacity of earth would be around 1 to 2 billion humans.

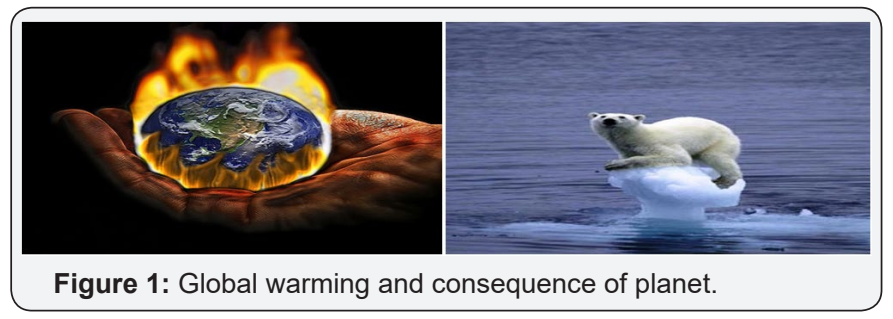

In 1896, Svante Arrhenius, a Swedish polymath and Nobel Prize winner was the first to propose the idea that burning fossil fuels could raise our planet's temperature. After doing a bunch of "tedious" calculations, he concluded that by "evaporating our coal mines into the air," humans could raise the temperature of the planet by five or six degrees Celsius [4]. This is harshly close to modern predictions made by computer-aided climate models. In the last few decades, humans have finally started to realize and accept that industrialization and infinitegrowth capitalism systems that have given some of us in the developed nations some luxuries, but have definitely increased atmospheric greenhouse gas levels to the point where we're all headed toward a hotter, more unstable home globe. The most ironic thing is that, in the next few decades, as our oil-soaked socioeconomic systems continue to untangle, the poorest and least developed populations with the lowest carbon dioxide $\left(\mathrm{CO}_{2}\right)$ emissions will face the direst consequences of humaninduced climate change. The World Bank has estimated that 


\section{Recent Advances in Petrochemical Science}

$75-80 \%$ of the effects of climate change are being felt by the least developed countries. On the other hand, about $70 \%$ of emissions have been produced by the richest $20 \%$ of the population (Figure 1).

Global warming is an average increase in the temperature of the atmosphere near the Earth's surface and in the troposphere, which can contribute to changes in global climate patterns [5]. Global warming can occur from a variety of causes, both natural and human induced [6]. Commonly, "global warming" often refers to the warming that can occur as a result of increased emissions of greenhouse gases from human activities." Causes of global warming are numerous. Some of which include $\mathrm{CO}_{2}$ emission, methane emissions from animals, increased use of chemical fertilizers on crop lands, deforestation, wet land reclamations, fossil fuel used, burning plants and industrial pollution. The Intergovernmental Panel on Climate Change (IPCC) states that the increase in global atmospheric concentration of carbon dioxide $\left(\mathrm{CO}_{2}\right)$ is primarily due to fossil fuel use and in a smaller but still significant level, to land-use change [5]. The World Bank has estimated that 75$80 \%$ of the effects of climate change are being felt by the least developed countries. On the other hand, about $70 \%$ of emissions have been produced by the richest $20 \%$ of the population. This is an informative review article, where author has tried to describe the effect of global warming and awareness of every individual and approach to solution in brief.

\section{Effect of Global Warming}

According to the World Bank (WB) "turn down the heat" report, the world is likely to get warmer by 4 degrees Celsius or 7.2 degrees Fahrenheit by 2100 . The reports showed that by 2030 , about 40 percent of land currently used for agriculture, would be unable to yield any crop due to drought. By 2050, the number of under-nourished people in the extreme climate region is expected to rise by 25-90 percent, compared to the current population. The scientists tell us that if the world warms by $2{ }^{\circ} \mathrm{C}$, warming which may be reached in 20 to 30 years, that will cause widespread food shortages, unprecedented heatwaves and more intense cyclones. Global warming increases of earth temperatures which affect both the flora and fauna [7]. Due to global warming, dissolved oxygen in the water is likely to be less owing to high temperatures and this is bound to also affect organisms like phytoplankton on which the fish can feed upon. Fish mainly need this oxygen for survival and when limited, it means their size is likely to reduce by $20 \%$ between 2001 and 2050. This is therefore bound to affect 600 or more fish species of which the fish industry will be disrupted much as people's diets and lively hoods [8]. Tony McMichael, director of the National Centre for Epidemiology and Population Health at the Australian National University has said that, recent extreme climatic events have underscored the risks to human health and survival [9].
In a recent chilling assessment, the World Health Organization (WHO) reported that human-induced changes in the Earth's climate now lead to at least 5 million cases of illness and more than 150,000 deaths every year. Temperature fluctuations may sway human health in a surprising number of ways, scientists have learned, from influencing the spread of infectious diseases to boosting the likelihood of illnessinducing heat waves and floods. WHO has shown that the growing health impacts of climate change affect different regions in markedly different ways [10]. Ironically, the places that have contributed the least to warming the Earth are the most vulnerable to the death and disease higher temperatures can bring. As temperatures climb and oceans warm, tropical and subtropical regions will face sharp changes in annual rainfall, says the Intergovernmental Panel on Climate Change (IPCC) report (Figure 2).

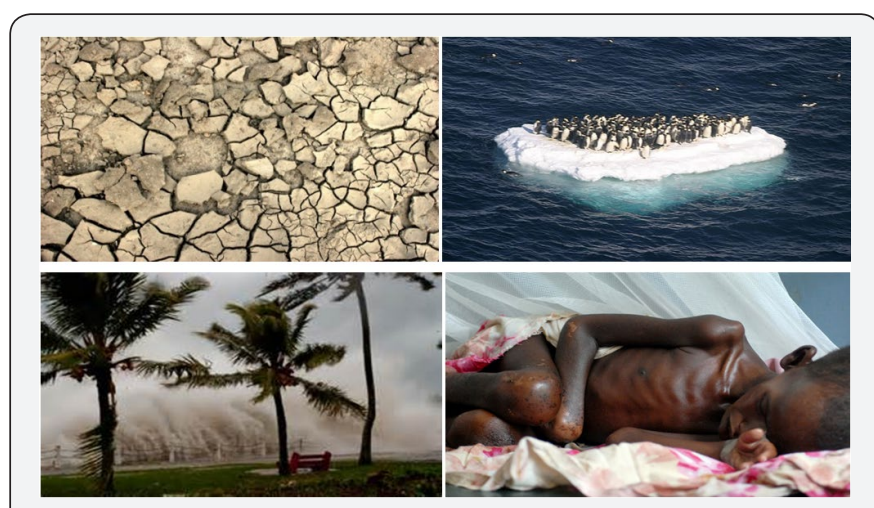

Figure 2: Few Pictures of Effects of Global Warring (Water crisis, ice melting, cyclone, and hunger).

It is virtually certain that in the long term, global precipitation will change. High latitude countries, such as in Europe or North America, are expected to receive more rainfall, but many subtropical arid and semi-arid regions will likely experience less precipitation. Over wet tropical regions, extreme precipitation events will very likely be more intense and more frequent in a warmer world. Monsoon onset dates are likely to become earlier or not to change much while monsoon withdrawal rates are very likely to delay. As a result, it is lengthening the season. Scientists have also lowered projections of sea-level rises. Depending on future greenhouse gas emissions, sea levels will raise an average of $16-24$ inch or $40-62 \mathrm{~cm}$ by 2100 . Nevertheless, there will be significant geographical variations. Many millions of people living in the developing world's great cities, including Lagos and Calcutta, are threatened. Weather disasters are also more likely in a warmer world, the report suggests. Although the global frequency of tropical cyclones is expected to decrease or remain essentially unchanged, they may become more intense, with stronger winds and heavier rainfall [11]. Oxfam predicted that world hunger would worsen as climate change inevitably hurt crop production and disrupted incomes. They suggested 


\section{Recent Advances in Petrochemical Science}

the number of people at risk of hunger might climb by $10 \%$ to $20 \%$ by 2050 , with daily per-capita calorie availability falling across the world.

Global warming will affect Poor Countries the Most. The World Bank Group says that global warming will lead to a major food-crisis in the future. Sub-Saharan Africa and Southeast Asia are expected to be the worst-hit. Global warming is expected to cause major changes in climate- from causing drought in some regions to causing severe storms in others. Places such as Jakarta and Ho Chi Minh City are considered to be "hotspots" for the climate change as these places will be badly affected by sea-level rise and severe tropical storms. Low-lying countries such as Kiribati are already sinking due to climate change and rising population. The German watch Climate Risk Index, which ranks the countries according to their extreme weather risks, shows that all countries in the top ten of this index are developing countries, led by Bangladesh, Myanmar and Honduras. 95\% of fatalities from natural disasters in the last 25 years occurred in developing countries. Developing countries do not have a history of large emissions of green house gases and thus have not contributed significantly to the causes of climate change [12]. So it is in the responsibility of the industrialized countries, which have caused the problem, to support the people in the developing countries to mitigate climate risks and help them to adapt to the changes.

Poor countries in Latin America, South America, subSaharan Africa, South Asia and Southeast Asia including Bangladesh are demanding rich countries that have benefitted from 150 years of unabated carbon dioxide emissions pay their dues. They claim that if the developed nations want to restrict the emissions of the developing nations, they need to pay for the technological leap to bypass the early, dirty stages of modernization and energy production as well as provide funding to deal with the current and future effects of climate change. In 2010, the United Nations Framework Convention on Climate Change (UNFCCC) established something called the green climate fund in order to facilitate the transfer of money from rich nations to poor nations so they could mitigate and adapt to the consequences of climate change. Currently, the richest nations have agreed to contribute up to US $\$ 100$ billion a year by 2020. This is not an official agreement. However, it's still unclear exactly how this fund will be collected and distributed. So far, only a fraction of the money has been pledged and it's mainly gone to cover startup costs. It's a whole lot of money to organize and facilitate during high-risk times and it's also necessary.

A 2013 report on the vulnerability of cities around the world to climate change showed that Dhaka, the capital of Bangladesh, is facing the most immediate and extreme effects from our fossil-fuel guzzling. Dhaka has one of the lowest $\mathrm{CO}_{2}$ emissions of any major city in the world at 0.6 tons per person per year. Almost half of the 13 million people of Dhaka live in low-lying, crowded slums and rarely have access to clean water, let alone electricity or personal vehicles. If we compare their annual emissions with the US (average 18 tons per person) or Canadian (average 16 tons per person), we can start to see exactly how unfair the situation is. If we go down the list of the cities, most threatened by climate change we'll find similar cases. So it is clear that, low GDPs and $\mathrm{CO}_{2}$ emissions, high risks for environmental catastrophes. This is just one more area of life where the poor are being screwed by the rich. The United States is responsible for $29 \%$ of all human emissions of carbon dioxide since the mid-19 ${ }^{\text {th }}$ century. As of today, they has emissioned around, 328,000,000,000 metric tons of $\mathrm{CO}_{2}$. True equitation is that, about $70 \%$ of emissions have been produced by the richest $20 \%$ of the population. The World Bank has estimated that $75-80 \%$ of the effects of climate change are being felt by the least developed countries. Ugandan President Yoweri Museveni has labelled climate change as "an act of aggression by the rich against the poor".

At the UN Earth Summit in Rio in 1992, Fidel Castro gave an impassioned speech about the ecological debts owed to the global poor. His words remain impressively insightful. He told that, an important biological species is in danger of disappearing due to the fast and progressive destruction of its natural living conditions. We have now become aware of this problem when it is almost too late to stop it. It is necessary to point out that consumer societies are fundamentally responsible for the brutal destruction of the environment [13]. They arose from the old colonial powers and from imperialist policies which in turn engendered the backwardness and poverty which today afflicts the vast majority of mankind. With only $20 \%$ of the world's population, these societies consume two-thirds of the metals and three-fourths of the energy produced in the world. They have poisoned the seas and rivers, polluted the air, weakened and punctured the ozone layer, saturated the atmosphere with gases which are changing weather conditions with a catastrophic effect we are already beginning to experience. The forests are disappearing. The deserts are expanding. Every year thousands of millions of tons of fertile soil end up in the sea [3]. Numerous species are becoming extinct [8]. Population pressures and poverty trigger frenzied efforts to survive even when it is at the expense of the environment. We are already seeing the effects of climate change in Bangladesh and across south Asia. It's not news to us. Most developing countries are facing climate change now [10]. They do not need the IPCC to tell them that the weather is changing", said Saleemul Huq, director of the International Centre for Climate Change and Development, based in Dhaka.

According to the Nature report, regions at highest risk for enduring the health effects of climate change include coastlines along the Pacific and Indian oceans and sub-Saharan Africa. Large sprawling cities, with their urban "heat island" effect, are 
also prone to temperature-related health problems. Africa has some of the lowest per-capita emissions of greenhouse gases. Yet, regions of the continent are gravely at risk for warmingrelated disease. Co-author Diarmid Campbell-Lendrum of WHO has said that, many of the most important diseases in poor countries, from malaria to diarrhea and malnutrition, are highly sensitive to climate.

\section{Combined Awareness to Help Climate}

Climate change is real, it is happening, and it is affecting the poorest, most vulnerable humans most of all. If our species wants to avoid widespread suffering and massive battles over resources due to millions or billions of climate refugees, we're going to have to come together to work on solutions that should not based on the capitalist logic of return on investment [14]. The return on this investment is survival. It is really surprising that, the United States, the world's top emitter of greenhouse gases, has yet to ratify the Kyoto treaty. It is moral obligation of countries with high per-capita emissions, such as the U.S. and European nations, to adopt a leadership role in reducing the health threats of global warming. The large, fast-growing economies, such as China and India, need to develop sustainable energy policies. Our combined awareness can ease/improve the situation and safe our beloved world.

In order to effectively address global warming, we should significantly reduce the amount of heat-trapping emissions we are putting into the atmosphere [15]. Burning fossil fuels such as natural gas, coal, oil and gasoline raises the level of carbon dioxide in the atmosphere and carbon dioxide is a major contributor to the greenhouse effect and global warming [16]. We should help to reduce the demand for fossil fuels, which in turn reduces global warming, by using energy more wisely. The good news is that we have the technology and practical solutions at hand to accomplish it. As individuals, we can help by taking action to reduce our personal carbon emissions. But to fully address the threat of global warming, we must demand action from our elected leaders to support and implement a comprehensive set of climate solutions. We should expand the use of renewable energy and transform our energy system to one that is cleaner and less dependent on coal and other fossil fuels [17]. We should increase vehicle fuel efficiency and support other solutions that reduce oil use [18]. We should place limits on the amount of carbon that polluters are allowed to emit. We should build a clean energy economy by investing in efficient energy technologies, industries, and approaches [19]. We should reduce tropical deforestation and its associated global warming emissions [20]. The Clean Air Act requires the Environmental Protection Agency (EPA) to take steps to reduce air pollution that harms the public's health. This includes global warming emissions, which the EPA has found to jeopardize public health. Today power plants are allowed to dump unlimited amounts of carbon pollution into the atmosphere. There are no rules in effect that limit their emissions of carbon dioxide, the primary driver of global warming [21]. We should implement some viable rules to solve this problem. We must raise fund and donate poor and third world countries, which effect climate least and affected severely.

\section{Individual Awareness to Help Climate}

The biggest cause of global warming is the carbon dioxide released when fossil fuels, mainly oil and coal are burned for energy. So when we save energy, we fight global warming and save money, too. Ever wonder how our tiny carbon footprint really impacts the big picture of climate change? Though we might feel like our lifestyle is insignificant compared to things like oil extraction or vehicle emissions, the choices we make in our day-to-day life. How we get around, what we eat, how we live, etc, play a major role in slowing climate change. Few tips and individual awareness can help climate and we can make better world.

Transportation causes about 25\% greenhouse gas emissions. So we should walk, cycle or take transit whenever we can. Besides saving gasoline, walking and biking are great forms of exercise. We'll save money and get into better shape! If we can't go car-free, try carpooling or car sharing and use the smallest, most fuel-efficient vehicle possible.

Save electricity and reduce global warming by turning off lights when we leave a room, and using only as required as we need. We should Change light bulbs to compact fluorescents light (CFL) or LEDs. Replacing just one 60-watt incandescent light bulb with a CFL will save you $\$ 30$ over the life of the bulb. CFLs also last 10 times longer than incandescent bulbs, use two-thirds less energy, and give off 70 percent less heat [22]. If every U.S. family replaced one regular light bulb with a CFL, it would eliminate 90 billion pounds of greenhouse gases, the same as taking 7.5 million cars off the road.

We should unplug computers, TVs and other electronics when not in use. Wash clothes in cold or warm water, not in hot water. Dryers are energy hogs, so hang dry when we can. Install a programmable thermostat. We should look for the low energy consumption label, when buying new appliances [23]. A home energy audit is cheaper, but effective. We can find more ways to save energy. Our utility need to switch account to clean, renewable power source; such as from wind farms, solar panel, etc.

We should buy organic and locally grown foods. We should avoid processed items. We should grow some of our own food. We should eat low on the food chain; at least one meat-free meal a day. $18 \%$ of greenhouse gas emissions come from meat and dairy production [24]. We should eat food, not too much and mostly plants. 
Garbage buried in landfills produces methane, a potent greenhouse gas. If we reduce our household garbage by $10 \%$, we can save 1200 pounds of carbon dioxide annually. We should keep stuff out of landfills by composting kitchen scraps and garden trimmings, and recycling paper, plastic, metal and glass [25]. We should store managers and manufacturers know we want products with minimal or recyclable packaging

Carbon taxes make polluting activities more expensive and green solutions more affordable and allowing energy-efficient businesses and households to save money. They are one of the most effective ways to reduce climate impact. If our province doesn't have a carbon tax, we should ask our premier to implement it. Air travel leaves behind a huge carbon footprint. Before we book our next airline ticket, consider greener options; such as buses or trains or we should try vacationing closer to home [26]. We can also stay in touch with people by videoconferencing, which saves time as well as travel and accommodation costs.

We should follow the latest news about climate change. We should share information about recycling and energy conservation with our friends, neighbors and co-workers and take opportunities to encourage public officials to establish programs and policies that are good for the environment. We should contact your political representatives and the media to tell them we want immediate action on climate change [9]. Remind them that reducing greenhouse gas emissions will also build healthier communities, spur economic innovation and create new jobs. Many organizations, working hard on solutions to climate change and rely on financial support from citizens. We should donate in such organization as much as convenience. We should buy products with minimal packaging (including the economy size when that makes sense for us) will help to reduce waste. By recycling half of your household waste, we can save 2,400 pounds of carbon dioxide annually. So whenever we can, we should recycle paper, plastic, newspaper, glass and aluminum cans.

\section{We Should Weatherize our Home or Apartment}

Heating and cooling consume about $40 \%$ of energy in the home. We should sealing drafts and making sure that our home has adequate insulation are two easy ways to become more energy-efficient [1]. Adding insulation to our walls and attic and installing weather stripping or caulking around doors and windows can lower our heating costs more than $25 \%$, by reducing the amount of energy we need to heat and cool your home.

We should turn down the heat while we're sleeping at night or away during the day and we should keep temperatures moderate at all times [27]. Setting our thermostat just 2 degrees lower in winter and higher in summer we could save about 2000 pounds of carbon dioxide each year. When we drive, make sure our car is running efficiently. For example, keeping our tires properly inflated, we can improve our gas mileage by more than $3 \%$. If all Americans kept their tires properly inflated, gasoline use nationwide would come down $2 \%$. A tune-up could boost your miles per gallon anywhere from 4 to $40 \%$, and a new air filter could get you $10 \%$ more miles per gallon. Every gallon of gas we save not only helps your budget; it also keeps 20 pounds of carbon dioxide out of the atmosphere [28].

We should buy low-flow showerheads to save hot water and about 350 pounds of carbon dioxide yearly. We should wash our clothes in warm or cold water to reduce our use of hot water and the energy required to produce it. This change alone can save at least 500 pound of carbon dioxide annually in most households. Use the energy-saving settings on our dishwasher and let the dishes air-dry. It's also a good idea to turn off the water when we're not using it. While brushing our teeth, shampooing the dog or washing our car, turn off the water until we actually need it for rinsing. We'll reduce our water bill and help to conserve a vital resource.

If we have the means to plant a tree, we should start digging. During photosynthesis, trees and other plants absorb carbon dioxide and give off oxygen. They are an integral part of the natural atmospheric exchange cycle here on Earth, but there are too few of them to fully counter the increases in carbon dioxide caused by automobile traffic, manufacturing and other human activities [29]. A single tree will absorb approximately one ton of carbon dioxide during its lifetime.

\section{We Should Choose an Efficient Vehicle}

High-mileage cars such as hybrids and plug-in hybrids use less gas and save money. Over its lifetime, a 40-mpg car will save roughly US $\$ 3,000$ in fuel costs compared with a 20 -mpg car.

\section{Conclusion}

Depending on future greenhouse gas emissions, sea levels will raise an average of 16-24inch or $40-62 \mathrm{~cm}$ by 2100 . Nevertheless, there will be significant geographical variations. Many millions of people living in the developing world's great cities are threatened. Global warming will affect Poor Countries the Most. The World Bank Group says that global warming will lead to a major food-crisis in the future. SubSaharan Africa and Southeast Asia are expected to be the worst-hit. World Health Organization (WHO) reported that human-induced changes in the Earth's climate now lead to at least 5 million cases of illness and more than 150,000 deaths every year. The consumptive lifestyles of rich are having lethal impacts on other people around the world, especially the poor. There are options now for leading more energy-efficient lives that should enable people to make better personal choices. Developing countries are Most Affected by Climate Change and 
Need the Support of the industrialized countries to Adapt to the Unavoidable Risks. It is moral obligation of countries with high per-capita emissions, such as the U.S. and European nations, to adopt a leadership role in reducing the health threats of global warming [27]. The large, fast-growing economies, such as China and India, need to develop sustainable energy policies. It is unwise to blame the Third World countries for this [30].

Climate change is real, it is happening, and it is affecting the poorest, most vulnerable humans most of all. If our species wants to avoid widespread suffering and massive battles over resources due to millions or billions of climate refugees, we're going to have to come together [31-35]. The biggest cause of global warming is the carbon dioxide released when fossil fuels, mainly oil and coal are burned for energy. So when we save energy, we fight global warming and save money, too. How we get around, what we eat, how we live, etc, play a major role in slowing climate change [36-40]. If we want to save mankind from this self-destruction, we have to better distribute the wealth and technologies available in the world. Less luxury and less waste by a few countries is needed so there is less poverty and less hunger on a large part of the Earth [41-46]. Let hunger disappear, and not mankind. All selfishness, hegemonies, insensitivity, irresponsibility, and deception should be ended now. We are already too late.

\section{References}

1. Barbara F (2003) Coal: A Human History Cambridge MA. Perseus Publishing.

2. Ruddiman WF (2010) Plows Plagues, and Petroleum: How Humans Took Control of Climate. Princeton University Press, p. 240.

3. Christopher HS (2009) Global Warming and the Problem of Policy Innovation: Lessons from the Early Environmental Movement. Environmental Law 39(2): 285-307.

4. Spencer R, Weart (2003) The Discovery of Global Warming. Harvard University Press, USA, p. 240.

5. Thomas L, Hannah L (2005) Climate Change and Biodiversity. Yale University Press, New Haven, USA.

6. John V (2013) Guardian Global development on Friday 27 September 2013.

7. Tennesen M (2008) The Complete Idiot's Guide to Global Warming. Penguin Publisher, USA.

8. Schmidt CW (2008) In Hot Water: Global Warming Takes a Toll on Coral Reefs. Environ Health Perspect 116(7): A292-A299.

9. Flannery $\mathrm{T}$ (2005) The Weather Makers: How Man Is Changing the Climate and What It Means for Life on Earth. Text Publishing Co, Melbourne, Australia.

10. Rowland MJ (2010) Will the Sky Fall in? Global Warming-An Alternative View. Antiquity 84(326): 1163-1171.

11. Greg HO (2011) Updating Our Understanding of Climate Change in the North Atlantic: The Role of Global Warming and the Gulf Stream. Geography 96(1): 5(11).

12. Bruce (2002) the Global Warming Desk Reference. Johansen Greenwood Press, pp. 373.
13. Amory L, Hunter L (1999) Natural Capitalism: Creating the Next Industrial Revolution. Little Brown Publishers, New York.

14. Knauer K (2007) Global Warming: The Causes, the Perils, the Solutions. Time Inc, New York.

15. Anita P, Julie R (2009) Gallup Presents, a Heated Debate Global Attitudes toward Climate Change. Harvard International Review 31(3): 64-68.

16. Cracken M, Michael C, Moore F, Topping J (2008) Sudden and Disruptive Climate Change. Exploring the Real Risks and How We Can Avoid Them London 32(2): 171-173.

17. Gustave SJ (2005) Red Sky at Morning: America and the Crisis of the Global Environment. Yale University Press, USA, pp. 320.

18. French CA, Perkins JH (1999) The Consumer's Guide to Effective Environmental Choices: Practical Advice from the Union of Concerned Scientist. Environmental Practice 1(4): 258-259.

19. Alley RB (2000) the Two-Mile Time Machine: Ice Cores, Abrupt Climate Change and Our Future. Princeton University Press, USA, p. 248.

20. Schneider, Stephen H, Terry R (2002) Wildlife Responses to Climate Change. Island Press, Washington DC, USA.

21. Wearth S (2007) the outstanding and authoritative history of global warming science. Princeton and the American Institute of Physics. The Discovery of Global Warming

22. Dauncey G, Patrick M (2001) Stormy Weather. New Society Publishers, Gabriola Island, Canada.

23. Diamond J (2005) Collapse: How Societies Choose to Fail or Succeed. Viking Publishers, New York, USA, p. 592.

24. Dow, Kirstin, Thomas E (2006) Downing: The Atlas of Climate Change. Berkeley. University of California Press, USA.

25. Elizabeth C (2004) The River Runs Black: The Environmental Challenge to China's Future. Ithaca, Environ Health Perspect 112(17): A1032.

26. Collins (2006) Fragile Earth: Views of a Changing World. Collins Publishers, London.

27. Hawken P (2006) Blessed Unrest. Viking Publishers, New York, USA, p. 352 .

28. Gore $\mathrm{Al}$ (2006) An Inconvenient Truth. Emmaus, PA. Rodale Publisher, USA.

29. Thomas G, Crutzen P (1995) Atmosphere, Climate, and Change. Scientific American Library, New York, USA.

30. David W (2009) Down to the Wire: Confronting Climate Collapse. Oxford University Press, the Journal of Environmental Education 46(3): 202-203.

31. Houghton JT (1994) Global Warming: The Complete Briefing (Paperback), Penguin Publishers, USA.

32. http://www.nrdc.org/globalWarming/fgwscience.asp

33. http://ioc.unesco.org/iocweb/climateChange.php

34. http://www.globalchange.gov/usgrcp

35. http://earthobservatory.nasa.gov

36. http://www.ipcc.ch

37. Christianson GE (1999) Greenhouse: The 200-Year Story of Global Warming. New York. Walker Publishing.

38. Houghton J (1997) Global Warming: The Complete Briefing. You have free access to this content. Eos, Transactions American Geophysical Union 79(33): 251. 
39. Elizabeth E (2006) Field Notes from a Catastrophe: Man, Nature, and Climate Change. Bloomsbury Publishing, New York, USA, p. 240.

40. Howard KJ (2005) The Long Emergency: Surviving the End of Oil, Climate Change and Other Converging Catastrophes of the Twenty-first Century. Atlantic Monthly Press, New York, USA, p. 336.

41. Lynas M (2004) High Tide: The Truth about Our Climate Crisis. Picador, New York, USA, p. 384.

42. Cracken M, Michael C, Frances M, Topping J (2008) Sudden and Disruptive Climate Change. Exploring the Real Risks and How We Can Avoid Them. Earthscan, London, p. 326.
43. Susanne M, Lisa D (2006) Creating a Climate for Change: Communicating Climate Change and Facilitating Social Change. Cambridge. Cambridge University Press, UK.

44. Pollack H (2005) Uncertain Science and Uncertain World. Cambridge, Cambridge University Press, UK.

45. Paroma B (2005) Third World bears brunt of global warming impacts.

46. The Health Effects of Global Warming: Developing Countries Are The Most Vulnerable.

\section{Your next submission with Juniper Publishers} will reach you the below assets

- Quality Editorial service

- Swift Peer Review

- Reprints availability

- E-prints Service

- Manuscript Podcast for convenient understanding

- Global attainment for your research

- Manuscript accessibility in different formats

( Pdf, E-pub, Full Text, Audio)

- Unceasing customer service

Track the below URL for one-step submission https://juniperpublishers.com/online-submission.php 